\title{
FROM THE PERSON TO THE INSTITUTION: RELIGIOUS FREEDOM AND INSTITUTIONS IN DEMOCRATIC STATES
}

DOI: http://dx.doi.org/10.12775/TiCz.2021.017

\begin{abstract}
Based on the assumption that the fundamental rights of people in most democratic states are governed by the personalist principle and that, of course, the religious freedom of the individual is an indisputable fundamental right, this paper reflects on the implications of these premises in the institutional field.

The article consists of four chapters: the first two chapters are of a more general nature, and the next two chapters apply the general principles to the Spanish context.

The first part discusses the personalist foundation that forms the basis of laws in democratic states. The author highlights the fact that the ethical value of the dignity of every human person provides an axiological foundation for the rules and fundamental laws enacted in the democratic constitutional order.

The second part of the paper is devoted to the principle of subsidiarity, which - in a way - constitutes a bridge that makes it possible to transpose the dignity of the person to the functioning of the institutions that operate within a democratic state. Subsidiarity is an essential complement to personalism as it prioritizes the activity of the person that should be supported by the institutions of the State.

The application of these general principles to the situation in Spain exemplifies them in the context of the understanding and enforcement of the right to religious freedom. By presenting specific legal solutions implemented in Spain in recent years, the author illustrates the challenges that the right to religious freedom is facing in modern democracies. The paper offers a compelling study of the joint effect of the principle of secularism in a democratic State and the principle of cooperation between the State and religious institutions (a concept referred to in the Spanish model as "positive secularism")
\end{abstract}


as they act upon social life to guarantee the implementation of a fundamental right of human persons: the right to religious freedom.

Keywords: religious freedom; person; institution; democracy.

Streszczenie. Od osoby do instytucji: wolność religijna a instytucje w państwach demokratycznych. Opierając się na założeniu, że podstawowe prawa człowieka w większości państw demokratycznych podlegają zasadzie personalistycznej i że oczywiście wolność religijna osoby jest niekwestionowanym prawem podstawowym, autor zastanawia się w niniejszym artykule nad implikacjami tych kwestii w przestrzeni instytucjonalnej.

Artykuł składa się z następujących elementów: dwa pierwsze mają charakter ogólny, dwa kolejne są aplikacją zasad ogólnych do kontekstu hiszpańskiego.

Część pierwsza ukazuje personalistyczny fundament stanowiący podstawę prawną w państwach demokratycznych. Autor naświetla, iż etyczna wartość godności każdej osoby ludzkiej jest aksjologiczną podstawą dla zasad i podstawowych praw ustanawianych w demokratycznym porządku konstytucyjnym.

Druga część tekstu poświęcona jest analizie zasady pomocniczości - która jest swoistym mostem pozwalającym przejść od godności osoby do funkcjonowania instytucji działających w ramach demokratycznego państwa. Zasada pomocniczości stanowi konieczne uzupełnienie zasady personalizmu, nadając priorytet aktywności osoby, która winna być wspierana przez instytucje państwowe.

Aplikacja tych ogólnych zasad do sytuacji w Hiszpanii stanowi ich egzemplifikację w kontekście rozumienia i egzekwowania prawa do wolności religijnej. Autor, ukazując konkretne rozwiązania prawne podjęte w Hiszpanii w ostatnich latach, ukazuje trudności, z jakimi musi się mierzyć we współczesnej demokracji prawo do wolności religijnej. To znakomite studium możliwości współoddziaływania na życie społeczne zasady laickości demokratycznego państwa oraz zasady współdziałania państwa $z$ instytucjami religijnymi (w modelu hiszpańskim ta koincydencja nosi nazwę sekularyzmu pozytywnego) w celu zagwarantowania realizacji podstawowego prawa osób ludzkich, jakim jest prawo do wolności religijnej.

Słowa kluczowe: wolność religijna; osoba; instytucja; demokracja.

\section{THE PERSONALIST FOUNDATION OF FUNDAMENTAL RIGHTS IN DEMOCRATIC STATES, WITH SPECIAL REFERENCE TO THE RIGHT TO RELIGIOUS FREEDOM IN THE SPANISH CASE}

The fundamental rights recognized by the constitutional orders of the current liberal democracies find one of their axiological foundations in a basic principle: the personalist principle. While it was the old formalist conceptions that paved the way for the constitutional positivism of the 
first half of the twentieth century, new trends began to emerge after the Second World War, both internationally and nationally, that proclaimed this principle on the basis of a fundamental reference to personal dignity as a pre-state legitimizing value that has its legal-constitutional expression par excellence in fundamental rights. ${ }^{1}$

Personal dignity presupposes that the primary subject of fundamental rights is the person individually considered. In this way, any collective projection of the person must necessarily start from that personal dimension in the sense that the person constitutes - and must constitute - an end in itself insofar as it possesses its own dignity. The ethical value of the dignity of the human person, therefore, constitutes the fundamental axiological referent of the principles and fundamental rights in any democratic constitutional order.

At the constitutional level, this implies the conversion of the personal dignity of a human being into a properly legal value. From the moment that the constitutional texts explicitly recognize this ethical value, it also becomes a legal value and, therefore, acquires full legal objectification, with a full normative status that imposes it obligatorily as mandatory. From the pre-state, it becomes integrated into the state, thus acquiring all the qualities that can be legally predicated of any constitutional norm, both with regard to the technical conditions of its constitutional interpretation and application and in relation to the requirements of a service nature that may be placed upon the State and the public authorities to guarantee its observance and safeguarding.

The inclusion of personal dignity in the most important objective rule of law of the entire order, such as the constitution, also entails its axiological implementation, by virtue of its value, in all state activity so that all of it is inevitably impregnated both in the order of its legitimacy and, of course, in that of its legality. This means, mutatis mutandis, the assumption of a personalistic ethic as the foundation of fundamental rights, of their derived rights, of the actions of public authorities and, therefore, of non-

1 In the field of Spanish Constitutionalism, see for example: F. Fernández Segado (ed.), Dignidad de la persona, derechos fundamentales, Justicia Constitucional, Madrid 2008, pp. 175-237; and J. Ruiz-Giménez Cortés, "Derechos fundamentales de la persona, comentario al artículo 10 de la Constitución," in Comentario a las Leyes Políticas, vol. I, ed. Ó. Alzaga Villaamil, Madrid 1984, p. 94. 
state social authorities and of citizens in general. ${ }^{2}$ Naturally, personal dignity as a legal value must also govern all constitutional hermeneutics constantly updating itself - in all areas of the legal activity of the State in order to guarantee its constant validity.

This legal personalism does not end here, but rather incorporates a perspective of personal dignity that is projected in the socio-historical dimension of human life whereby the person is conceived of not only as a simple individual considered in isolation, but also as a social being by nature. Thus, legal personalism is an anthropological conception that mediates between liberal individualism and totalitarian collectivism insofar as the person - as representative of the human - constitutes a unique and irreplaceable totality and, therefore - as the well-known aphorism says - is the measure of all law. Naturally, this also includes the rights of greater personal transcendence: fundamental rights, both in their purely individual dimension and in the socio-historical dimension (within the Spanish constitutionalist doctrine, Pablo Lucas Verdú calls it "community personalism"). ${ }^{3}$

This way of understanding fundamental rights has been endorsed by the Catholic Church since the Second Vatican Council, especially with regard to the fundamental right to religious freedom. The Declaration Dignitatis Humanae (December 7, 1965) proclaims that religious freedom constitutes a natural right of man within a civil society. In Section 2, it explicitly states:

This Vatican Council declares that the human person has a right to religious freedom. This freedom means that all men are to be immune from

2 This has been theorized and interpreted from, above all, German constitutionalism after the Second World War in line with Article 1.1 of the Basic Law of Bonn, which reads as follows: "Human dignity is intangible. Respecting it and protecting it is the obligation of every public power" (G. Dürig, "Kommentar zum GG, Art. 1," in Th. Maunz and G. Dürig, GG Kommentar, München 1976, footnote 1.1, p. 1-I.3).

3 P. Lucas Verdú, Estimativa y política constitucionales, Madrid 1984, p. 123. For a discussion of how this legal personalism has been received through the value of personal dignity in the constitutions and continental European constitutionalism, see: A. Oehling de Los Reyes, "El concepto constitucional de dignidad de la persona: formas de comprensión y modelos predominantes de recepción en la Europa continental," Revista española de Derecho constitucional 91 (2011), pp. $140 \mathrm{ff}$. 
coercion on the part of individuals or of social groups and of any human power, in such wise that no one is to be forced to act in a manner contrary to his own beliefs, whether privately or publicly, whether alone or in association with others, within due limits. The council further declares that the right to religious freedom has its foundation in the very dignity of the human person as this dignity is known through the revealed word of God and by reason itself. This right of the human person to religious freedom is to be recognized in the constitutional law whereby society is governed and thus it is to become a civil right.

It is my view that in the legal-normative field, this doctrine has been projected in almost all current democratic constitutional texts on the dogmatic plane of the fundamental rights. Thus, for example, it was faithfully reflected in the Spanish Constitution of 1978, whose Article 16 states:

1. Freedom of ideology, religion and worship of individuals and communities is guaranteed, with no other restriction on their expression than may be necessary to maintain public order as protected by law.

2. No one may be compelled to make statements regarding [his or her] religion, beliefs or ideologies.

3. There shall be no State religion. The public authorities shall take the religious beliefs of Spanish society into account and shall consequently maintain appropriate cooperation with the Catholic Church and the other confessions.

In this way, within the context of religious pluralism in the social sphere and of religious indifferentism on the part of the State, the fundamental right to religious freedom is enshrined from a personalistic perspective. If, therefore, fundamental rights are considered to constitute legal-positive formulations of the dignity of the person, it is only possible that the person is the center of gravity around which everything concerning the religious question must revolve. 


\section{FROM THE PERSON TO THE INSTITUTION: THE PRINCIPLE OF SUBSIDIARITY AS THE MEDIATOR BETWEEN THE TWO SPHERES}

Notwithstanding the above, the ethical-legal articulation of the value of human dignity from a personal perspective in relation to fundamental rights requires the concurrence of another principle that enables its real and practical effectiveness: the principle of subsidiarity. The Compendium of the Social Doctrine of the Church is clear in formulating this principle:

On the basis of this principle, all societies of a superior order must adopt attitudes of help ("subsidium") - therefore of support, promotion, development - with respect to lower-order societies. In this way, intermediate social entities can properly perform the functions that fall to them without being required to hand them over unjustly to other social entities of a higher level, by which they would end up being absorbed and substituted, in the end seeing themselves denied their dignity and essential place.

Subsidiarity, understood in the positive sense as economic, institutional or juridical assistance offered to lesser social entities, entails a corresponding series of negative implications that require the State to refrain from anything that would de facto restrict the existential space of the smaller essential cells of society. Their initiative, freedom and responsibility must not be supplanted. ${ }^{4}$

Consequently, anyone who wants to pursue activities aimed at the common good must be provided by the public authorities with the freedom and the conditions needed to carry them out and must be granted the necessary assistance so that such activities are not carried out at a high level of action when they can be done at a lower level.

We see, therefore, that the principle of subsidiarity constitutes a fundamental and necessary complement to the personalist principle, since it gives ethical priority to the action of the person, trying to promote the person and, ultimately, to respect the person's own dignity. In this sense, personal dignity is understood as the foundation of fundamental rights (including, of course, the right to religious freedom) in the current

4 Compendium of the Social Doctrine of the Church, sec. 186 (https://www.vatican.va/ roman_curia/pontifical_councils/justpeace/documents/rc_pc_justpeace_doc_20060526_ compendio-dott-soc_en.html), retrieved on November 11, 2020. 
democracies, since - starting from the value of dignity - the fundamental right to religious freedom is articulated in concurrence with the subsidiarity principle. What occurs here is the transformation from value to law, inevitably passing through the beginning, as a way of being legally articulated.

In view of the above, as a principle of social ethics, subsidiarity directly presupposes an appeal for the participation of social institutions and the State in complement with the action of the human person, under a certain form of relationship where the person represents the starting point on the way to achieve his or her own happiness and the common good. Therefore, such a principle plays a mediating role between the person and the institution (and, therefore, between the person and the State), which, structurally, allows the person, in its purely social dimension, to perform individually and contribute to the common good when it comes to making their fundamental rights effective.

\section{RELIGIOUS FREEDOM AS A FUNDAMENTAL RIGHT OF THE PERSON IN THE INDIVIDUAL DIMENSION WITH REGARD TO THE SPANISH CASE: FREEDOM OF CONVICTION AND THE PRINCIPLE OF EQUALITY}

The aforementioned constitutional proclamation of religious freedom as a fundamental right in Spain can be considered, to a great extent, paradigmatic, since the Spanish legal system is in that respect a very meaningful example of what can be understood by such a fundamental right in a current democratic regime. Hence, it serves as a point of reference for our presentation at a general level.

In the Spanish Constitution of 1978, this fundamental right has a generic character, since it is specified in different freedoms and more specific rights which stem from a certain historical configuration that is inserted into the tradition of the modern theory of rights and which addresses the following issues: freedom of conviction (and, correspondingly, the right to conscientious objection), the principle of equality, the principle of secularism and the principle of cooperation. Freedom of conviction and equality have an eminently individual projection here, while the remaining two present a more markedly collective dimension. 
a) Freedom of conviction (and conscientious objection)

In the Spanish constitutional order, this is a fundamental subjective right that can be understood from two points of view:

1) as an informing principle of any legal system (of a political and social organizational nature) and as the backbone of the relations between the Church and the State; and

2) as a fundamental subjective right that is granted to people in relation to the public authorities and other citizens.

Let us now see in more detail how the two requirements are specified, which in turn presents two dimensions of the matter - one negative and the other positive:

A) Negative dimension: Freedom of conviction presupposes abstentionism on the part of public authorities as a basic principle of freedom of conviction. The State is not legally empowered to make any declaration of confession (or non-denominationalism) with respect to any religion, and, naturally, it cannot impose such a declaration in a compulsory or coercive manner on citizens, since it would go against their freedom of conviction. The same is true of citizens' acts of faith or belief (including atheism, agnosticism or religious indifference) for the same reasons. In this way, the State cannot be, in any case, an active subject of attitudes or acts of a religious or ideological nature, whether in coexistence, substitution or by means of coercion towards its citizens, and must therefore limit itself in that respect to a merely protective function as a guarantor of that fundamental right.

A second negative aspect is that, according to Article 16.2 of the Spanish Constitution, the State cannot force anyone to make declarations about their ideology, religion or beliefs. This should not be understood in an absolute sense, since it is possible for the State to ask such questions in certain matters and circumstances (for example, in relation to religious teaching or religious assistance), always under a guaranteeing justification of the freedom of conviction to facilitate its exercise in the sense of reinforcing it, never diminishing it, and never with a discriminatory intention with respect to the person whose manifestation (or non-manifestation) is required. ${ }^{5}$

5 In this sense, the Spanish Constitutional Court pronounced in its judgment 38/2007 of February 15 concerning the right to religious education, and more specifical- 
B) Positive dimension: It is specified in the requirement concerning the active conduct of the State in relation to freedom of conviction, as established in Article 9.2 of the Constitution, in its general provision requiring the public authorities to remove any obstacle that prevents or impairs its exercise and effective promotion. ${ }^{6}$ In this order of ideas, the State is required to carry out a normative activity that allows and guarantees the full exercise of this fundamental freedom and promotes the factual conditions for its exercise. Likewise, the State must contemplate the freedom of religious and ideological conviction to the maximum extent possible in accordance with the general legal principle of "maximum possible freedom, minimum necessary restriction": not only to allow to do, but also to do, for the sake of free training and development of human consciousness and personality.

Finally, due to its essential link with freedom of conscience, citizens' fundamental right to conscientious objection, must not be forgotten here. Generically, it consists of the right to oppose, for religious, ideological or conscientious reasons, the fulfillment of obligations and duties prescribed in a general way by the legal system. It is constitutionally recognized in Article 30.2, with a specific reference to conscientious objection to military service and what is known as the journalists' conscientious

ly the requirement of an ecclesiastical declaration of suitability for teachers of religion in public educational centers: "The requirement of having an ecclesiastical declaration of suitability to be able to teach religion in educational centers [...] cannot be understood as violating the individual right to religious freedom (Article 16.1 of the Constitution) of teachers of religion, nor the prohibition of any obligation to make statements regarding their religion (Article 16.2 of the Constitution), principles that are only affected to the strict extent necessary to make them compatible with the right of the churches to impart their doctrine within the framework of the public educational system (Articles 16.1 and 16.3 of the Constitution) and with the right of parents to religious education of their children (Article 27.3 of the Constitution). It would be simply unreasonable for religious teaching in schools to be carried out without taking into consideration as a criterion for selecting teachers the religious convictions of the people who freely decide to attend the corresponding jobs, and this, precisely, in guarantee of their own right to religious freedom in its external and collective dimension."

6 Article 9.2 of the Constitution states: "It is incumbent upon the public authorities to promote conditions which ensure that the freedom and equality of individuals and of the groups to which they belong may be real and effective, to remove the obstacles which prevent or hinder their full enjoyment, and to facilitate the participation of all citizens in political, economic, cultural and social life." 
clause (Article 20.1.d) of the Constitution). ${ }^{7}$ However, the Constitutional Court has also recognized the objection of doctors and health personnel in relation to the voluntary interruption of pregnancy (judgment 53/1985 of April 11) and with practices related to assisted reproduction (judgment $116 / 1999$ of June 17). Consequently, it can be stated that conscientious objection is not generally admitted in the Spanish legal system, hence it has been denied, for example, in the cases in which it is fenced to avoid being part of polling stations (judgments of Chamber 3 of January 30, 1979 and October 28, 1998); or also the so-called tax conscientious objection. ${ }^{8}$

This thesis is reinforced by the fact that, for example, in relation to the subject of "Education for citizenship" as provided for in Organic Law 2/2006 of May 3 on Education (which has led to numerous conflicts in the judicial sphere in reference to conscientious objection to its compulsory nature in the educational system), the Spanish Supreme Court has established that there is no absolute constitutional right to conscientious objection, not even as a projection of Article 16 of the Constitution, because it finds its limit in the law (appeal no. 905/2008). The argument is based on Article 9.1 of the Constitution ${ }^{9}$ in the sense that such absolute existence would mean conditioning the legal norms to each personal conscience. It

7 Article 30.2 of the Constitution says: "The law shall determine the military obligations of Spaniards and shall regulate, with the proper safeguards, conscientious objection as well as other grounds for exemption from compulsory military service; it may also, when appropriate, impose a form of social service in lieu thereof." Furthermore, Article 20.1.d) states that "the right to freely communicate or receive accurate information by any means of dissemination whatsoever [is recognized and protected]. The law shall regulate the right to invoke personal conscience and professional secrecy in the exercise of these freedoms."

8 Conscientious objection adopts its most problematic profile in cases of conflict between religious, conscientious and ideological freedom and the right to life, where its weighting can become truly dramatic. The general argumentation that is usually imposed in these cases is the assessment of such conflicts from the position of the person; however, the Constitutional Court has tended to impose the duty to protect life in specific cases of people who are under special protection of the State (judgments 120/1990 of June 27 and 137/1990 of July 19) and of people who have not reached the age of majority or who, even so, do not have sufficient maturity (judgment 154/2002 of July 18) in such a way that special treatment that is compatible cannot be imposed on public health with the faith or ideology of the affected person, nor a reimbursement of the expenses incurred in private healthcare for such reasons (judgment 166/1996 of October 28).

9 Article 9.1 of the Constitution says the following: "Citizens and public authorities are bound by the Constitution and all other legal provisions." 
would only be conscientious objection to military service that is likely to be recognized with this character, in such a way that any other recognition will depend, strictly speaking, on the will of the legislator.

\section{b) The principle of equality}

The Spanish constitutional model echoes the two paradigmatic ways of understanding equality in current democratic systems: as equality of the law and as equality before the law. The former is understood, in a general way, as a principle of non-discrimination of people, motivated by the generality that characterizes all democratic legal norms, while the latter postulates the requirement of a qualitatively equal treatment of the different subjects in a normative plane. ${ }^{10}$

In the field of the fundamental right to religious freedom, these two ways of understanding equality have been interpreted in an exemplary way by the Constitutional Court in its judgment 24/1982 of May 13 in the sense that any guarantee of the principle of religious equality implies the absence of any different legal treatment of people on account of their ideology, belief or conviction, as well as the power to hold an equal enjoyment of the fundamental right to freedom of conscience by all citizens.

However, equal treatment should not be understood as uniformity in treatment; as the Constitutional Court points out, it must be understood, rather, as qualitative proportionality (judgment of July 2, 1981) in such a way that it does not imply equal, univocal legal treatment without taking into account any differentiating elements of legal relevance. It is, therefore, a treatment modulated according to the specific circumstances that concur in each case in relation to which it is invoked (judgment of July 10, 1981). Consequently, within the complex axiological context that makes up a social and democratic State of Law such as Spain, it is possible to grant citizens an unequal treatment that results from the need to make effective the cardinal values that are constitutionally proclaimed as superior in the legal system in the frontispiece of the constitutional text: freedom,

10 This is stated in Article 14 of the Constitution: "Spaniards are equal before the law and may not in any way be discriminated against on account of birth, race, sex, religion, opinion or any other personal or social condition or circumstance." 
justice, equality and political pluralism (Article $1.1^{11}$ ). The arguments of the Constitutional Court, therefore, support the conclusion that equality should not be understood in an absolute and univocal sense, but rather (as said above) in terms of qualitative proportionality.

Under these hermeneutical parameters, at the legal level, religious discrimination would be understood as any prohibition of any action of differentiation or distinction for religious reasons that implies an impairment or extinction of the ownership and exercise of the right to freedom of conscience and the rest of the fundamental rights. In this line, in the field of international law, the definition given in Article 2.2 of the Declaration on the Elimination of All Forms of Intolerance and of Discrimination Based on Religion or Belief, according to which "intolerance and discrimination based on religion or belief' mean any distinction, exclusion, restriction or preference based on religion or belief and having as its purpose or as its effect nullification or impairment of the recognition, enjoyment or exercise of human rights and fundamental freedoms on an equal basis."

At the level of the exercise of fundamental rights, in relation to the principle of equality, it should be taken into account that the previous constitutional prohibition of discrimination is not univocal, either, in the sense of always requiring the need to prescriptively recognize the differences that may exist in people under the specific situations in which they may occur, since it is one thing to discriminate and quite another to differentiate based on such different objective situations. Differentiation in treatment is linked to subjective reasons that do not occur in discrimination. ${ }^{12}$

In short, the absolute prohibition of discrimination is constitutionally affirmed at the legal level in the face of discrimination in exercise, and must be modulated in accordance with the specific and subjective circumstances that may occur in certain cases which would reasonably justify such discrimination. Specifically, in relation to freedom of religion and belief, equality does not imply that all Spanish citizens must profess the same

11 Article 1.1 of the Constitution says: "Spain is hereby established as a social and democratic State, subject to the rule of law, which advocates as the highest values of its legal order, liberty, justice, equality and political pluralism."

12 G. Suarez Pertierra, "Artículo 14. Igualdad ante la ley," in Villaamil, op. cit., p. 286. 
religious or ideological beliefs or convictions, nor that they should be treated in the same way in this regard. Rather, it must be understood as qualitative equality and treatment before (in and of) the law. Therefore, the legal equality declared in Article 14 of the Constitution is a formal and relative equality, based on the principle of qualitative proportionality, against a material and absolute equality. In any case, it is necessary to relate the aforementioned Article 14 to Article 9.2, which comes to complete and underpin the principle of equality, since it refers to the material aspect of it. In this sense, Article 9.2 fulfills two functions: to establish the defense and protection of the principle of formal equality and to demand from the public authorities the necessary actions for its effective implementation. Under these two generic prescriptions, on the one hand, public authorities are obliged to promote the necessary conditions so that religious equality (and freedom, incidentally) of social groups and citizens are real and effective (promotive function of equality on the part of the public authorities); and on the other hand, they are also obliged to remove any obstacle that hinders or prevents the full realization of such equality (and of freedom). The articulation of these effective guarantees of the principle of equality, both in a positive and negative sense, authorizes the imposition, de facto, of positive discrimination in some specific cases in order to achieve real and effective material equality.

4. AGAIN FROM THE PERSON TO THE INSTITUTION:

RELIGIOUS FREEDOM AS A FUNDAMENTAL RIGHT IN ITS COLLECTIVE DIMENSION (THE PRINCIPLE OF SECULARISM AND THE PRINCIPLE OF COOPERATION BETWEEN THE STATE AND RELIGIOUS CONFESSIONS)

It is now time to look at the political and social dimensions of the religious question; that is to say, its institutional implications. The institution represents a common space for the relationship of the rights and freedoms of people among themselves for the sake of the common good; it is a space of mediation between the person individually considered and the society in which they live (and, obviously, also between the person and the State as the main social subject). Hence, the institution is the place that allows the fundamental rights of the person to be materialized and 
made effective, and is thus inevitably required to adequately understand all issues related to them.

In the Spanish framework and in democratic states in general, the passage from the personal level to the institutional level - in relation to the freedom of religious conviction in its relationship with the principle of equality - occurs on the basis of two fundamental principles which make their institutional explicitness possible and, therefore, come to complete them: the principle of secularism of the democratic State and the principle of cooperation between the State and religious confessions. ${ }^{13}$

\section{a) The principle of secularism}

This principle means the separation of the State from any religious confession, as well as its neutrality with respect to any such confession. In this sense, one may talk of a positive secularism - respectful of the religious fact in all its manifestations - as a cultural factor of prime importance in any democracy worth its salt. ${ }^{14}$

b) The principle of cooperation between the State and religious confessions

The union or collaboration between religious confessions and the State is not postulated here in the sense of attempting to achieve common ends, but rather in the sense of the protection and promotion by the latter of equality in the ownership of the freedom of religious and/or ideological conviction and in the exercise of that freedom by citizens. The main mode of institutional articulation of this principle is through the declaration and establishment of the legal statutes of the different religious confessions. Thus, it is a principle that seeks to make religious freedom really effective, to its maximum extent, at the institutional level.

Using the Spanish model as an example, if we take into account what has been said before about freedom of conscience and the principle

13 This issue, basically, will condition the models of relationship between religious freedom and the recognition of such freedom by the State in democratic states.

14 A detailed treatment of this issue in Spain can be found in: A. Ollero, "Laicidad positiva, igualdad consiguiente: diálogo sobre el artículo 16 de la Constitución española," Persona y Derecho 77 (2017) 2, pp. 93-131. 
of equality, we can conclude that, from an institutional point of view, this constitutes a political system presided over by the principle of secularism; a system where the keys to the vault are the fundamental rights to freedom of conviction and religious equality. This system is politically and legally predicated on a model of religious and ideological neutrality of the State and the public authorities that corresponds to what is doctrinally known as the secular State. This neutrality, as indicated by the Constitutional Court, implies the non-denominational status of the State and the need to establish and maintain cooperative relations with the different religious confessions (judgments 101/2004 of June 23 and 38/2007 of February 15). This principle of cooperation has led the Constitutional Court to define the Spanish model as a model of positive secularism (judgment 46/2001 of February 15).

This constitutional framework must be understood in the light of the general principles that govern the legal nature of fundamental rights. Indeed, as mentioned above, the Spanish Constitution starts from a conception of these in a primarily personalistic sense, in such a way that the collective dimension of such rights has a derivative or instrumental character which is, in certain respects, dependent on their individual dimension.

As regards the specific application of this idea in the religious sphere, the personalistic sense referred to above implies the logical and axiological priority of the fundamental rights of religious freedom and freedom of conviction over any model of relationship between the State and religion, so that the latter depends on - and is subject to, in a certain way - the guarantee and effective realization of this fundamental right from the point of view of the individual person.

This understanding of religious freedom as a fundamental right necessarily requires - for the sake of its recognition, confirmation and real effectiveness - an axiological context governed by the principle of religious and ideological pluralism: the only possible context in which true religious and ideological freedom of the person can be given and which guarantees that the person can choose between the different options that are presented to them. In itself, this implies a positive consideration of the religious phenomenon, as expressed in the right of citizens to freedom of conviction, and, consequently, the need for promotive action by the State 
which guarantees that the person has the power to act in accordance with it in their individual and social life by promoting the real conditions to make their exercise effective in this regard. The way in which this should be done must start with the assumption that religious freedom (unlike the remaining fundamental rights) does not have an absolute character, since, if it did, it would condition the legal regulations to the multiplicity of personal consciences of all citizens, which is impossible for technical reasons (the legal rule is general and abstract, not particular or concrete) and for reasons of social justice, since it is necessary to create and promote a common space of relationship between people (institutional space) where all particular freedoms can coexist. ${ }^{15}$

15 Certainly, this is how it is protected and guaranteed in the Spanish legal system as a whole as far as legislative instruments of constitutional development are concerned: the right to religious freedom under Article 16 is subject to the reservation of organic laws (Article 81 of the Constitution), which in any case must respect its essential content, and is binding on all public authorities (Article 53.1 of the Constitution). Furthermore, it has particularly strong jurisdictional guarantees such as the protection of ordinary courts through a procedure based on the principles of preference and summary and, alternatively, the protection of the Constitutional Court through an appeal for protection (Article 53.2 of the Constitution). The legislative and regulatory development of religious freedom is found in Organic Law 7/1980 of July 5 on religious freedom, which was in turn expanded upon by Royal Decree 142/1981 of January 9 on the organization and operation of the Registry of Religious Entities and by Royal Decree 1980/1981 of June 19 on the establishment of the Advisory Commission on Religious Freedom. In particular, the organic law regulates, in this sense, individual aspects (the right to profess any religious beliefs or not to profess any, the right to change religion, the right not to be obliged to make statements about one's ideas or the right not to be obliged to practice acts of worship, the right to receive religious education according to one's own convictions - or those of parents or guardians - and the right to receive a dignified burial), collective aspects (the right to celebrate one's own rites) and other aspects which, in many cases, are linked to other fundamental rights such as the right to impart religious education (Article 27 of the Constitution), the right to assemble or demonstrate (Article 21 of the Constitution) or the right to associate (Article 22 of the Constitution), in relation to which a special regime has been established. However, the generic recognition of rights may be limited in the concrete casuistry, as is the case, for example, with the declaration in the Organic Law of the right to commemorate holidays in accordance with religious beliefs and the fact that the exercise of this right is limited to account for the possibilities of organizing work. Here, the Constitutional Court interprets that the Sunday holiday no longer has the religious character that it had in its origin, but has become the traditional and generalized day of rest from work (judgment 19/1985 of February 13). 
In my opinion, this should be the general criterion that governs the will of the legislator when offering legislative proposals in relation to this complex and fundamental issue in current democratic systems so as to avoid reproducing crudely, once again, the old dialectic between clericalism and anti-clericalism, ${ }^{16}$ which - particularly in Spain - has proved so pernicious to the religious freedom of the people in the last two centuries.

\section{BIBLIOGRAPHY}

Alzaga Villaamil Ó. (ed.), Comentario a las Leyes Políticas, vol. I, Madrid 1984.

Compendium of the Social Doctrine of the Church, http://www.vatican.va/roman_curia/ pontifical_councils/justpeace/documents/rc_pc_justpeace_doc_20060526_compendio-dott-soc_en.html.

Diaz-Salazar R., El factor católico en la política española. Del nacionalcatolicismo al laicismo, Madrid 2006.

Fernández Segado F. (ed.), Dignidad de la persona, derechos fundamentales, Justicia Constitucional, Madrid 2008.

Lucas Verdú P., Estimativa y política constitucionales, Madrid 1984.

Maunz Th. and Dürig G., GG Kommentar, München 1976.

Oehling de los Reyes A., "El concepto constitucional de dignidad de la persona: formas de comprensión y modelos predominantes de recepción en la Europa continental," Revista española de Derecho constitucional 91 (2011), pp. 135-178.

Ollero A., "Laicidad positiva, igualdad consiguiente: diálogo sobre el artículo 16 de la Constitución española," Persona y Derecho 77 (2017) 2, pp. 93-131.

16 Despite everything, this dialectic is, de facto, still in force in Spain, both with regard to specific public policies on religious freedom and with regard to their management and execution. Even though more than four decades have passed since the approval of the constitutional text, this debate is still present daily in the political and social scene of Spain (R. Diaz-Salazar, El factor católico en la política española. Del nacionalcatolicismo al laicismo, Madrid 2006). 